\title{
Presence of Prionospio (Prionospio) orensanzi Blake, 1983 (Polychaeta: Spionidae) off Punta Arenas, Chile, with notes on their abundance and spatial distribution in shallow, subtidal sandy bottoms
}

\author{
Juan I. Cañete ${ }^{1}$, Brigitte Hilbig ${ }^{2} \&$ Mario Santana ${ }^{1}$ \\ ${ }^{1}$ Departamento de Ciencias y Recursos Naturales, Facultad de Ciencias \\ Universidad de Magallanes, Casilla 113-D, Punta Arenas, Chile \\ ${ }^{2}$ Universität Hamburg, Zoologisches Institut und Zoologisches Museum, \\ Martin Luther King Platz 3, 20146 Hamburg, Germany
}

\begin{abstract}
This paper confirm the presence of the spionid polychaete Prionospio (Prionospio) orensanzi Blake 1983, from a shallow, sandy, subtidal benthic area, between 5 and $20 \mathrm{~m}$ of depth, near to domestic wastewater and the

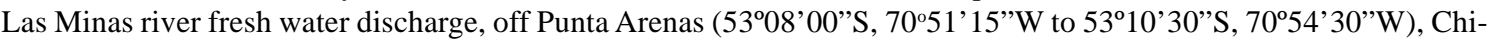
le. The external morphology of this specimens agree well with the original description of this species. $P$. (P.) orensanzi was collected together to 42 others polychaete species, where nine spionids species are listed. The family Spionidae was the most common of the polychaetes collected in the sampling area, with $P$.(P.) orensanzi being the most abundant species. This new record confirm the presence of this species in Chilean waters, increase to three the number of members of the genus Prionospio (Prionospio) on the Chilean coast, and nearly to 41 the total number of species of Spionidae from Chile. A key to the Chilean species of Prionospio is presented.
\end{abstract}

Key words: Polychaeta, subantarctic benthos, Prionospio (Prionospio) orensanzi, Magellan Strait.

Presencia de Prionospio (Prionospio) orensanzi Blake, 1983 (Polychaeta: Spionidae) frente a Punta Arenas, Chile, con notas sobre su abundancia y distribución espacial en fondos arenosos submareales someros

RESUMEN. Se confirma la presencia del poliqueto perteneciente a la familia Spionidae Prionospio (Prionospio) orensanzi Blake, 1983 en sedimentos arenosos submareales entre 5 y $20 \mathrm{~m}$ de profundidad, afectados por aguas servidas y descarga de agua dulce del río Las Minas, Punta Arenas (5308'00”S, 7051'15”W a 53¹0'30"S, 7054’30”W), Chile. Los especímenes recolectados coinciden en gran medida con la descripción original de Blake (1983). $P$. (P.) orensanzi fue recolectada junto a otras 42 especies de poliquetos, identificándose nueve especies pertenecientes a la familia Spionidae. Esta familia fue la más representativa en el área de muestreo por la riqueza de especies, donde $P .(P$.) orensanzi fue más abundante. Este nuevo hallazgo confirma la presencia de esta especie en aguas marinas chilenas, produciendo un incremento cercano a 41 especies en la familia Spionidae y a tres el número de miembros pertenecientes al género Prionospio (Prionospio). Se presenta una clave para identificar las especies del género Prionospio descritas para Chile.

Palabras clave: poliquetos, bentos subantártico, Prionospio (Prionospio) orensanzi, estrecho de Magallanes. 
The genus Prionospio (Prionospio) Malmgren 1867 includes species with smooth, non- pinnate and pinnate branchiae arranged in various combinations (Blake, 1983). Until now was represented in Chilean waters by two species (Rozbaczylo, 1985): Prionospio (Prionospio) cf elhersi Fauvel, 1928, a predominantly deep-sea species (Blake, 1983; Maciolek, 1985; Gage \& Tyler, 1991; Cañete et al., 1999a) and P. (P.) steenstrupi Malmgren, 1867, this last collected around off Juan Fernandez Island near to $46 \mathrm{~m}$ depth (Blake, 1983; Rozbaczylo, 1985).

An analysis of benthic polychaete fauna collected as part of an oceanographic cruises in 1991 in the Magellan Strait produced specimens with incomplete branchiae suggesting the presence of $P$. $(P)$. orensanzi in this region (Gambi \& Mariani, 1999). This species was previously reported from the coast of Argentina $\left(37^{\circ} \mathrm{S}\right.$, Blake, 1983) and its presence is now confirmed among the benthic macrofauna inhabiting a shallow, sandy bottom area between 2.5 to $20 \mathrm{~m}$ depth off Punta Arenas $\left(53^{\circ} \mathrm{S}\right.$, $\left.71^{\circ} \mathrm{W}\right)$ (Cañete, 2000).
This ecological evaluation was developed to know the shallow, marine benthic biodiversity in relation to potential effects produced by domestic wastewater and the influence of the Las Minas River discharge at the spatial dynamic. The present study documents the record of $P$. (P.) orensanzi along the coast off Punta Arenas, Chile, given preliminary data on the abundance and spatial distribution in the shallow sandy bottom studied. We had included, for reference, list with other spionid polychaetes obtained in the samples.

Sediments samples were collected in november, 1999 by a diver using a $0.0225 \mathrm{~m}^{2}$ Ekman-Birge grab sampler along twelve transects perpendicular to the coastal line (Fig. 1), with stations selected according to depth. One sample was taken at depths of 2, 5, 10 and 15 or $20 \mathrm{~m}$ depending on bottom morphology. The sediment samples were washed on a $0.5 \mathrm{~mm}$ mesh geological screen to collect the infauna, and animals were fixed in $4 \%$ seawater-formalin and preserved in $70 \%$ ethanol. The position of each sampling station were recorded using a Garmin Co.

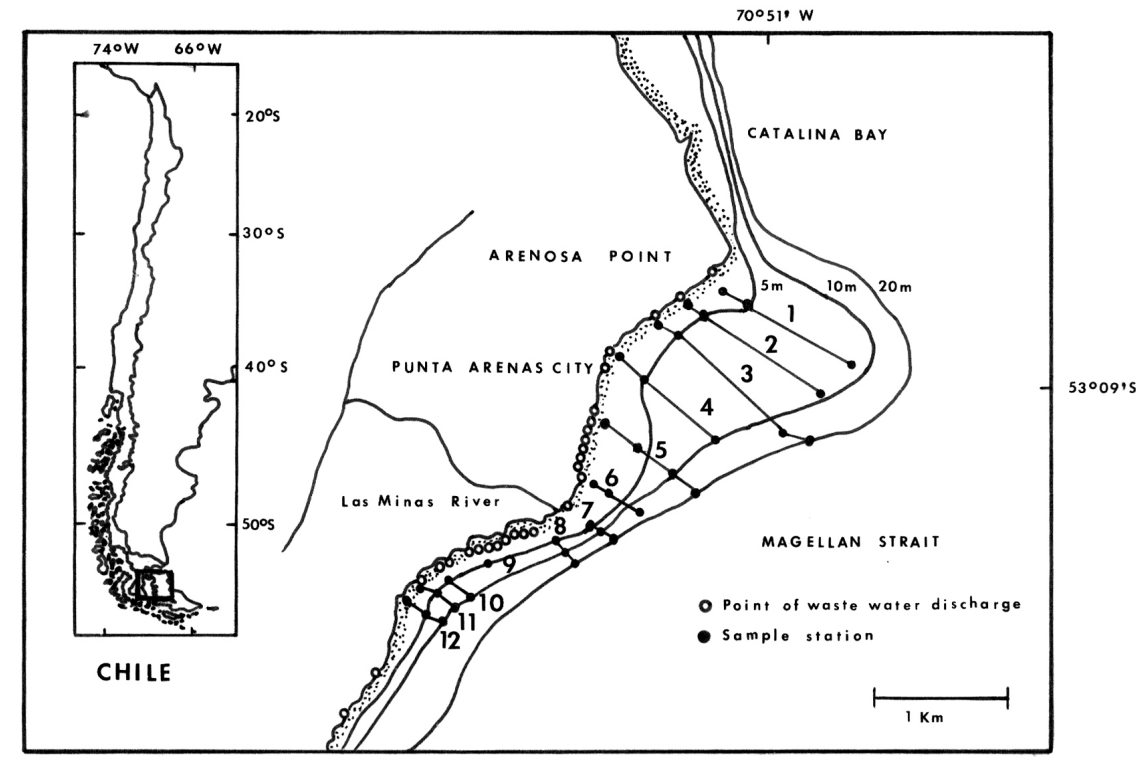

Figure 1. Spatial distribution of transects and sampling stations. White circles show the location of wastewater discharge and black circles the position of benthic sampling stations; numbers indicate transects. Samples of transect eight were lost. The mouth of Las Minas River is located near to the transect seven.

Figura 1. Distribución espacial de transectas y estaciones de muestreo (círculos negros). Círculos blancos muestran la localización de los emisarios que descargan aguas servidas; los números identifican las transectas. Las muestras de la trasecta ocho fueron perdidas. La boca del río Las Minas está localizada frente a la transecta siete. 
MK II global positioning system. Additional samples were obtained during August 1999, January and May, 2000 (Fig. 1; transects 10, 11 and 12).

Specimens were stained with methyl blue in $70^{\circ}$ ethanol to observe the branchial arrangement and the morphology of parapodial lobes and dorsal crest. Figures were provided through a system of image collections (Proseries Capture Kit MV ${ }^{\mathrm{TM}}$ version 1.0 for Windows produced by Media Cybernetics) connected to stereoscopic microscope and a camera, or mounting the camera on microscope. Scanning electronic microscope (SEM) photographs were obtained with a JEOL JSM-T300, on specimens which were crtitical-point dried using $\mathrm{CO}_{2}$ and a Samdri 780A Tousimis equipment. Specimens were gold coated for SEM observations using a JEOL JFC-1100 fine coat ion sputter (Rouse \& Pleijel, 2001).

Three identified specimens of $P$. (P.) orensanzi were deposited in the Systematic Room of Flora and Fauna Profesor Patricio Sánchez Reyes (code SSUC6914), Faculty of Biological Sciences, Pontificia Universidad Católica de Chile (SSUC). Additional samples were deposited at the collection of benthic polychaetes of the subantarctic Chilean coast in the Departamento de Ciencias y Recursos Naturales, Facultad de Ciencias, Universidad de Magallanes, Punta Arenas, Chile.

Prionospio (Prionospio) orensanzi Blake, 1983 (Figs. 2a-d)

Prionospio (Prionospio) orensanzi Blake, 1983, p. 225, Figs.10-11.

Prionspio (P.) cf orensanzi Gambi \& Mariani, 1999, p. 236.

Material examined: Punta Arenas, Chile


70'54'30”W), 5 to $20 \mathrm{~m}$ depth, J.I. Cañete \& B. Hilbig collectors, from shallow, sandy bottoms, November 22, 1999. 36 specimens: SSUC-Chile (3 specimens), and Collection of Chilean Polychaetes, Facultad de Ciencias, Universidad de Magallanes, Chile (rest of specimens).

Description: one specimen was selected for taxonomic description, measuring $17 \mathrm{~mm}$ long and $0.8 \mathrm{~mm}$ wide, with 64 setigers. Other specimens were 15 to $20 \mathrm{~mm}$ length, with 58 to 63 setigerous segments. Nearly all specimens were incomplete, being collected mainly the anterior ends. Color in alcohol: light tan to white. Segments increase in length from anterior to posterior. Posterior end acute. Prostomium triangular in shape twice as longer as wide; anterior margin varied in shape: broadly rounded in some specimens, with weak central incision; in others incision not observed, ocasionally the anterior end of prostomium recorded as undulated flap (Fig. 2a). Caruncle extends posteriorly as a low ridge to middle of setiger 2; long ciliated nuchal grooves occurring lateral to caruncle; two pairs of black eyes, posterior pair larger, irregular in shape, composed of numerous ocelli; anterior pair smaller. Peristomium reduced, lacking lateral wings.

Setiger 1 well developed, separated from peristomium, with broad notopodial lamellae and smaller, leaflike neuropodial lamellae (Fig. 2a); notopodial lamellae of setigers 2-5 large, triangular in shape (Fig. 2a); lamellae of setigers 6-19 continued across dorsum forming an evident dorsal crest (Fig. 2a); neuropodial lamellae of anterior and middle setigers rounded, slightly wider than long, becoming leaflike in posterior setigers. After setiger 19 , crest not detected and the segments longer than those located in the anterior end (Fig. 2b). Setigers 13-21 with incomplete ventral crests separated only in the central zone, being lowest than the dorsal crests; ridges located at posterior margin of each segment and fused to globular papillae located behind neuropodial lobes.

Branchiae present on setigers 2-5 (Fig. 2a), all of similar length; first and fourth pairs pinnate, second and third pairs cirriform. Branchial pinnules longer than detailed in original description.

Capillary notosetae of anterior and middle setigers unilimbate, arranged in 2 rows, those of anterior row being shorter, with wider sheaths than those of posterior row (Fig. 2a). Both types of setae with granulations on distal half of shaft. Capillary neurosetae bilimbate, arranged in two rows, also with granulations on shaft; neuropodia with thin inferior sabre setae from setiger 10 (Fig. 2b); multidentate hooded hooks in neuropodia from setiger 18 and in notopodia from setiger 36 with right shaft; hooks with 10-12 apical teeth arranged in 2 rows above main fang; internal hood inconspicuous; neuropodial hooks accompanied by 4-7 thin, bilimbate setae in each torus (Fig. 2c). Pygidium with a long central cirrus and two shorter anal cirri located to each side in the proximal end (Fig. 2d). 
$\mathbf{a}$

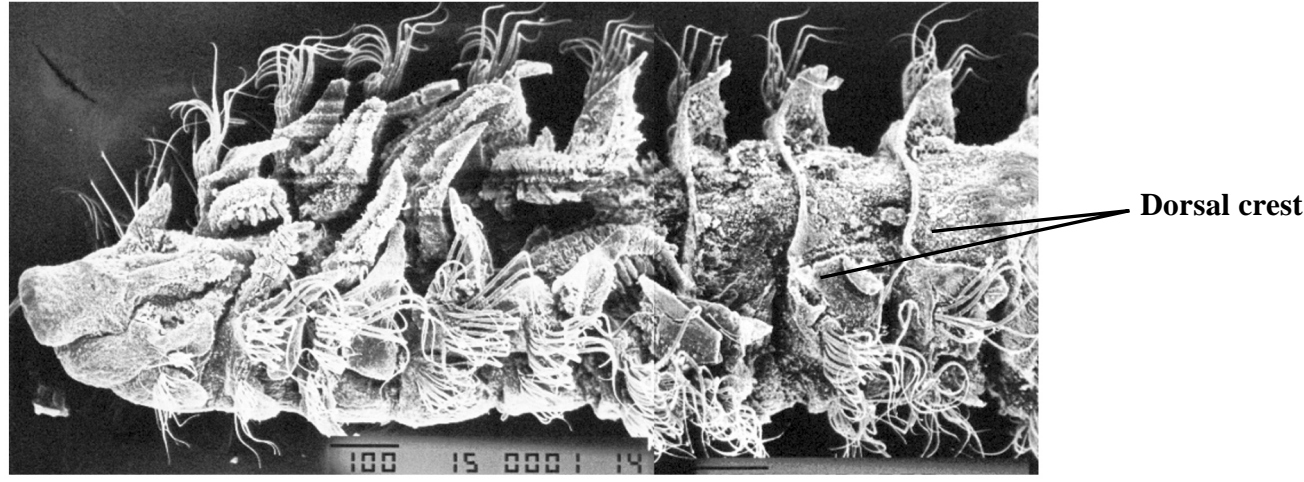

b
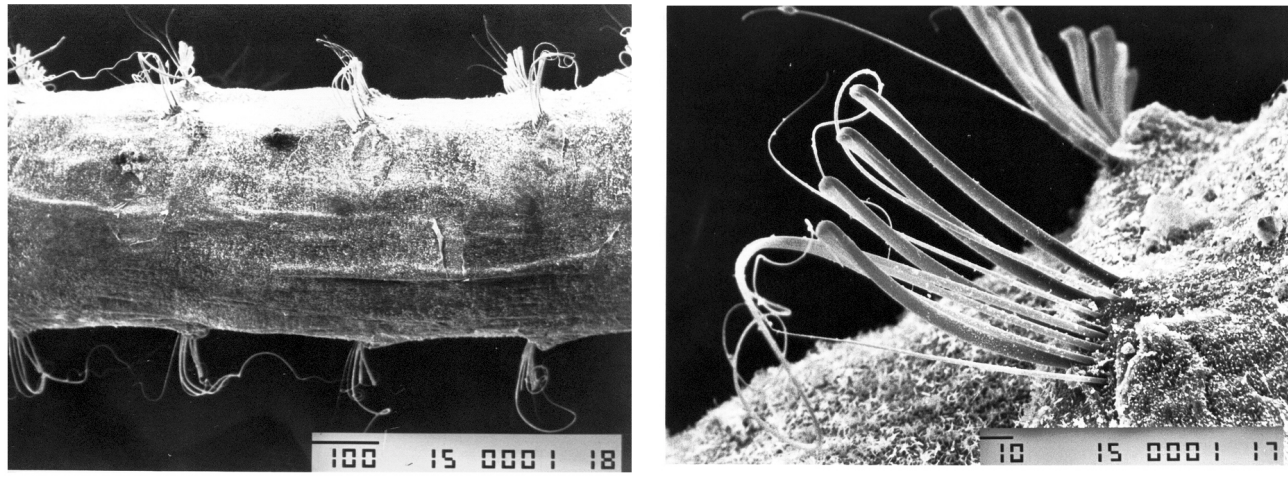

c

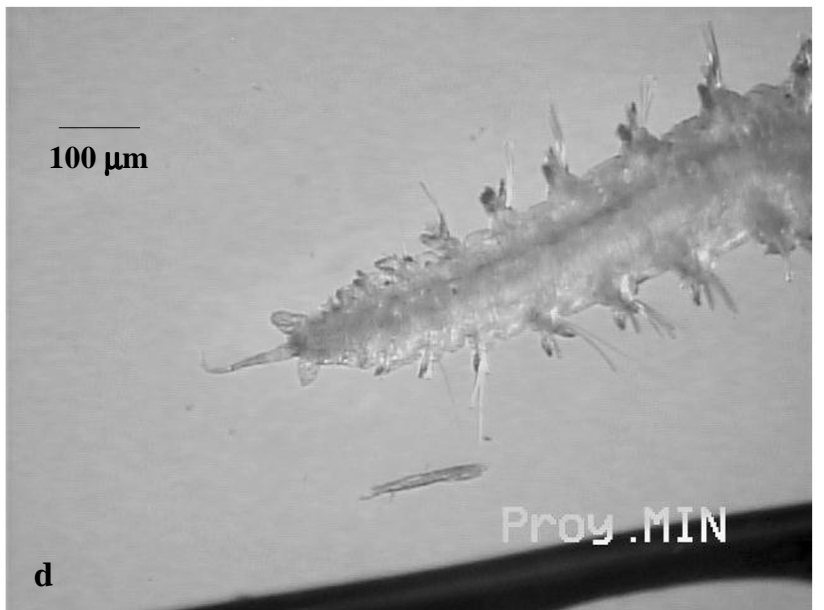

Figure 2. Prionospio (Prionospio) orensanzi Blake 1983. a) dorsal view of the anterior end, showing the branchial pattern and elevated dorsal crests, $b$ ) dorsal view of mid setigerous segments without dorsal crests, c) noto and neurosetae of mid setiger, $d$ ) ventral view of the pygidium and posterior end.

Figura 2. Prionospio (Prionospio) orensanzi Blake 1983. a) vista dorsal del extremo anterior, mostrando la organización de branquias y crestas dorsales, b) vista dorsal de segmentos setígeros medios del cuerpo, carentes de crestas dorsales, c) distribución y morfología de noto y neurocerdas de setígeros de la zona media del cuerpo, d) vista ventral del pigidio y extremo posterior del cuerpo. 
Geographic distribution: the present study extends the distributional range of Prionospio (Prionospio) orensanzi from its original locality $\left(37^{\circ} \mathrm{S}\right.$ to $\mathrm{San}$ Matías Gulf, south of Argentina; Blake, 1983) to Punta Arenas, Chile (this study), allowing to certify their presence in southern Chilean waters. Thus, it should be considered a typical representative of the Magellan Biogeographic Province or cold temperate regions (Moyano, 1982; Brattström \& Johanssen, 1983; Briggs, 1995; Cañete et al., 1999b; Lancellotti \& Vásquez, 2000). It is notoriously that in a specific study on the subtidal polychaetes from the San José Gulf, a small embayment within the San Matías Gulf, $P$. (P.) orensanzi neither others members of the family Spionidae were reported by Pastor de Ward (2000); the difference could be related to the presence of poorly sorted rock and coarse sand in San José Gulf, while fine sandy bottom dominates in the subtidal area off Punta Arenas.

Taxonomic notes: this species is representative the morphology of Punta Arenas specimens clearly coincide with Blake's (1983) original description. Diagnostic characters include the morphology and distribution of the branchiae and the elevated dorsal crests fused to the notopodial lamellae of the anterior notopodia (Fig. 2a). A weak medial incision in the anterior end of the prostomium was not observed in all Punta Arenas specimens. Furthermore, the latter posses branchial pinnules longer than figured in the original description, and the ventral crest were not reported by Blake (1983).

This finding increases to three the members of the genus Prionospio (sensu stricto) (Blake, 1983) reported from Chilean coast, and nearly to 41 the number of spionid polychaetes reported within politic limits of Chile (Rozbaczylo, 1985). A key to identify the three species reported for Chilean waters is given below.

\section{Dicotomous key to identify three species of the genus Prionospio (Prionospio) \\ (Polychaeta: Spionidae) from the Chilean coast}

1a. First pair of branchiae pinnate, others cirriferous P. (P.) elhersi

1b. Two pairs of branchiae cirriferous and two pairs pinnate . .2

2a(1b). Neuropodial hooks from setigerous 13 to 17 P. (P.) steenstrupi

$2 b(1 b)$. Neuropodial hooks from setigerous $20 \ldots .$. P. (P.) orensanzi

\section{Ecological notes}

This species is representative of shallow, sandy sediments off Punta Arenas, Chile, where nine species of spionid polychaetes have been collected in the present study (Table 1). The maximun abundance of $P$. (P.) orensanzi off Punta Arenas reach to 400 ind. $\cdot \mathrm{m}^{-2}$ (average $=3$ ind. $\cdot 0.0225 \mathrm{~m}^{-2}$ ) and the average abundance is higher in intermediate depths than in shallow and most deep stations. Some specimens were collected in all depths, except to 2 m stations (Fig. 3a). If the Gambi \& Mariani (1999) specimens are the same species reported by us, then the bathymetric distribution could be extended to $80 \mathrm{~m}$ depth.

P. (P.) orensanzi has a bimodal spatial distribution along the coastal line off Punta Arenas, where the discharge of Las Minas River and the presence of a shallow sand bar disrupt the population distribution (Fig. 3b). This situation could explain the absence of diverse species collected in this study between transects 7 and 9 along the coastaline. The effects of freshwater discharge on coastal benthos is a topic we plan to address in future research. Spionidae represent the family with highest number of species within all families of polychaetes

Table 1. List of species of the family Spionidae (Polychaeta) collected at subtidal sandy bottoms off Punta Arenas, Chile (n.r. = new record). Include only data on spionid polychaetes collected during November 1999.

Tabla 1. Lista de representantes de la familia Spionidae (Polychaeta) recolectados en sedimentos arenosos submareales frente a Punta Arenas, Chile. Considera sólo datos de muestras recolectadas en noviembre 1999.

\begin{tabular}{|lr|}
\hline Species & $\begin{array}{r}\text { Total } \\
\text { abundance }(\boldsymbol{\%})\end{array}$ \\
\hline Prionospio (P.) orensanzi (n.r.) & 33.3 \\
Spiophanes bombix & 14.2 \\
Caraziella sp. & 3.3 \\
Boccardia polybranchia $=$ B. wellingtonesis $*$ & 10.0 \\
Polydora spp. (2 species) & 3.3 \\
Spio sp. & 1.8 \\
Rhynchospio glutaea & 28.3 \\
Laonice sp. & 0.8 \\
Spionidae indeterminate & 5.0 \\
\hline
\end{tabular}

* According to Sato-Okoshi \& Takatsuka (2001). 
collected in the study area (Table 2), where 42 species were identified.

Finally, as in other embayments along the Chilean coast (Iquique, Valparaíso, Quintero and Concepción bay) studied by Quiroga et al. (1999), Rozbaczylo \& Salgado (1993), Cañete et al. (2000) and Carrasco (1974), respectively, spionid polychaetes attain high densities and ecological dominance in coastal bottoms off Punta Arenas. Furthermore, this family contributes nearly to $10 \%$ of the total richness of macroinvertebrates species (Cañete, 2000), being a very important taxon in to sustain the subantarctic biodiversity at shallow, sandy bottoms of this location.
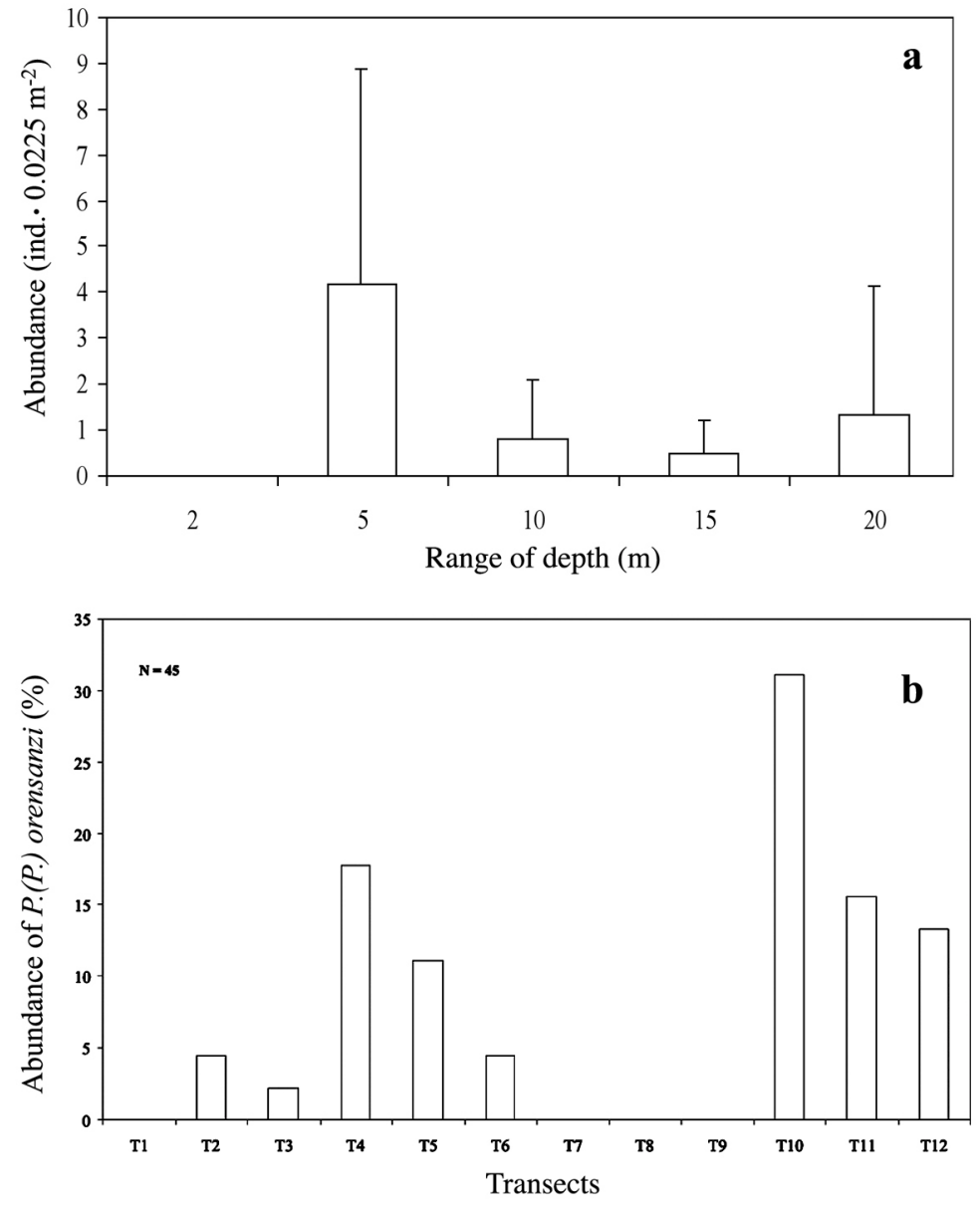

Figure 3. a) Mean abundance and bathymetric distribution of Prionospio (P.) orensanzi off Punta Arenas, Chile. Bars show the standard deviation. Data of August and November 1999 and January and May 2000 were grouped (Fig. 1, transects 10, 11 and 12) $(\mathrm{N}=160$ specimens collected), b) total abundance (as percentage) of Prionospio $(P$.$) orensanzi by transect along the coastal line off Punta Arenas (November, 1999).$

Figura 3. a) Variación batimétrica de la abundancia promedio de Prionospio (P.) orensanzi frente a Punta Arenas, Chile. Barras verticales indican la desviación estándar. Datos obtenidos en agosto y noviembre 1999, y enero y mayo 2000 se muestran agrupados (Fig. 1, transectas 10, 11 y 12) ( $\mathrm{N}=160$ especímenes), b) abundancia total (en porcentaje) de Prionospio (P.) orensanzi por transecta en el borde costero localizado frente a Punta Arenas (noviembre, 1999). 
Table 2. Species richness of benthic polychaetes families collected from sandy, subtidal bottom off Punta Arenas, Chile, in November 1999. Nomination to the order level based in Rouse \& Pleijel (2001).

Tabla 2. Riqueza de especies de cada familia de poliquetos bentónicos recolectados en sedimentos arenosos submareales localizados frente a Punta Arenas, Chile, noviembre de 1999. Clasificación a nivel de orden basada en la proposición de Rouse \& Pleijel (2001).

\begin{tabular}{|ccc|}
\hline Family & Order & $\begin{array}{c}\text { Richness of } \\
\text { species }\end{array}$ \\
\hline Capitellidae & Scolecida & 3 \\
Cossuridae & Scolecida & 1 \\
Maldanidae & Scolecida & 2 \\
Opheliidae & Scolecida & 1 \\
Orbiniidae & Scolecida & 1 \\
Paraonidae & Scolecida & 3 \\
Polynoidae & Aphroditiformia & 1 \\
Hesionidae & Nereidiformia & 1 \\
Nereididae & Nereidiformia & 1 \\
Pilargiidae & Nereidiformia & 1 \\
Syllidae & Nereidiformia & 2 \\
Glyceridae & Phyllodocida & 2 \\
Goniadidae & Phyllodocida & 1 \\
Nepthyidae & Phyllodocida & 2 \\
Phyllodocidae & Phyllodocida & 2 \\
Dorvilleidae & Eunicida & 1 \\
Lumbrineridae & Eunicida & 1 \\
Onuphidae & Eunicida & 2 \\
Cirratulidae & Cirratuliformia & 3 \\
Ampharetidae & Terebelliformia & 1 \\
Chaetopteridae & Spionida & 1 \\
Spionidae & Spionida & 10 \\
\hline Total & number of species & 42 \\
\hline
\end{tabular}

\section{ACKNOWLEDGMENTS}

We thank to the Dirección de Investigación, Universidad de Magallanes for financial support (Grant PY-F4-02RN-99). We thank to Prof. Nicolás Rozbazcylo (Pontificia Universidad Católica de Chile, Santiago, Chile) the deposit of specimens. We also thank to the Chilean Ministry of Education for the financial support of the project MINEDUCAcuicultura to Universidad of Magallanes which allowed availability of scientific equipment. We thank to M.Sc. Marisol Romero (Universidad Católica del Norte, Coquimbo, Chile) for SEM analysis and the diver Mr. Francisco Carrasco for field work.

\section{REFERENCES}

Blake, J.A. 1983. Polychaetes of the family Spionidae from South America, Antarctica, and adjacent seas and islands. In: Louis S. Kornicker (ed.). Biology of the Antarctic Seas XIV. Antarctic Res. Ser., 39: 205-288.

Brattström, H. \& A. Johanssen. 1983. Ecological and regional zoogeography of the marine benthic fauna of Chile. Sarsia, 68: 1-289.

Briggs, J.C. 1995. Global biogeography. Elsevier Science, Amsterdam, 678 pp.

Cañete, J.I. 2000. Biodiversity and community structure of the subtidal, benthic macrofauna living around waste-water discharge in the urban zone off Punta Arenas, Chile, and their role in the monitoring of the environment impact in subantarctic littoral areas. Final Report, Research Administration Office, Universidad of Magallanes, Punta Arenas, Chile, 15 pp.

Cañete, J.I., H.A. Sievers, P. Báez \& C. Valdovinos. 1999a. Macrobenthos of the continental slope off Mejillones Peninsula, northern Chile: results of the Atacama Trench International Expedition (september 1997). In: Atacama Trench International Expedition (ATIE), AGOR 60 "Vidal Gormaz" (September 1 to 6, 1997), Second Report, preliminary results. Universita di Genova, Istituto Scienze Ambientali Marine, Data Report 56, pp. 67-74.

Cañete, J.I., G.L. Leighton \& F.F. Aguilera. 1999b. Polychaetes from Aysen Fjord, Chile: distribution, abundance and biogeographical comparison with the shallow soft-bottom polychaete fauna from 
Antarctica and the Magellan Province. Sci. Mar., 63(Supl. 1): 243-252.

Cañete J.I., G.L. Leighton \& E. Soto. 2000. Proposición de un índice de vigilancia ambiental basado en la variabilidad temporal de la abundancia de dos especies de poliquetos bentónicos de bahía Quintero, Chile. Rev. Biol. Mar. Oceanogr., 35: 185194.

Carrasco, F.D. 1974. Spionidae (Polychaeta) provenientes de la bahía de Concepción y lugares adyacentes. Bol. Soc. Biol. Concepción, 48: 185-201.

Gage, J.D. \& P.A. Tyler. 1991. Deep sea biology. A natural history of organisms at the deep-sea floor. Cambridge University Press, Cambridge, 504 pp.

Gambi, M.C. \& S. Mariani. 1999. Polychaetes of the soft bottoms of the Strait of Magellan collected during the Italian Oceanographic cruise in February-March, 1991. Sci. Mar., 63(Supl. 1): 233242.

Lancellotti, D.A. \& J.A. Vásquez. 1999. Biogeographical patterns of benthic macroinvertebrates in the southeastern Pacific littoral. J. Biogeogr., 26: 1001-1006.

Maciolek, N.J. 1985. A revision of the genus Prionospio Malmgren with special emphasis on species from the Atlantic Ocean, and new records of species belonging to the genera Apoprionospio Foster and Paraprionospio Caullery (Polychaeta, Annelida, Spionidae). Zool. J. Linnean Soc., 84: 325-383.

Recibido: 16 diciembre 2002; Aceptado: 4 junio 2004
Moyano, H. 1982. Magellanic Bryozoa: some ecological and zoogeographical aspects. Mar. Biol., 67: 81-96.

Pastor de Ward, C.T. 2000. Polychaete assemblages in the San José Gulf (Chubut, Argentina), in relation to abiotic and biotic factors. P.S.Z.N., Mar. Ecol., 21: $175-190$.

Quiroga, E., R. Soto \& N. Rozbaczylo. 1999. Los poliquetos espiónidos (Polychaeta: Spionidae) y su importancia en la estructura de una comunidad: un caso de estudio en bahía Iquique, norte de Chile (20¹1'S, 70¹0'W). Gayana, 63: 1-16.

Rouse, G.W. \& F. Pleijel. 2001. Polychaetes. Oxford University Press, New York, 354 pp.

Rozbaczylo, N. 1985. Los anélidos poliquetos de Chile. Indice sinonímico y distribución geográfica de especies. Monografías Biológicas, Pontificia Universidad Católica de Chile, 3: 1-284.

Rozbaczylo, N. \& P. Salgado. 1993. Poliquetos Spionidae de fondos blandos submareales de la bahía de Valparaíso, Chile (Annelida: Polychaeta). Estud. Oceanol., 12: 17-28.

Sato-Okoshi, W. \& M. Takatsuka. 2001. Polydora and related genera (Polychaeta: Spionidae) around Puerto Montt and Chiloé Island (Chile), with description of a new species of Dipolydora. Bull. Mar. Sci., 68: 485-503. 